\title{
A Proposed Educational Role for Jordanian Universities to Integrate Education into Sustainable Development in the Educational Learning Process
}

\author{
Dr. Maram Fuad Abu Al Nadi ${ }^{1}$ \\ ${ }^{1}$ Basic Human Sciences Department, Petra University, Amman, Jordan \\ Correspondence: Dr. Maram Fuad Abu Al Nadi, Department of Education, Petra University, Amman, Jordan. \\ E-mail: doctornadi@yahoo.com/mabualandi@uop.edu.jo
}

Received: October 16, 2019

Accepted: November 13, 2019 Online Published: November 14, 2019

doi:10.5539/mas.v13n12p30

URL: https://doi.org/10.5539/mas.v13n12p30

\begin{abstract}
This study well shed some light on a proposed role for Jordanian universities to integrate education on sustainable development in the educational learning process, the study used the descriptive method, and a questionnaire of (30) terms has been set.

The validity of the tool was verified. 300 faculty members from Jordanian official universities namely: Jordan, Yarmouk and Mutata University, were randomly selected. The study concluded the following results:

-The opinion of the faculty members of Jordanian universities on the idea of integrating education with sustainable development in the educational process was moderate.

- The study showed differences in statistical semantics, depending on the type of the faculty, academic rank and gender, where these indications favored the scientific colleges, professorship rank and female sex.

- The study hopes that the Ministry of Higher Education will take the concept of sustainable development in the educational process to enhance cooperation between universities and public and private institutions in society, in order to develop new and innovative disciplines that meet the needs of the new stage.
\end{abstract}

Keywords: educational role, Jordanian Universities, principles of education, education, development, sustainable development

\section{Introduction}

Societies are eager to achieve their goals and aspirations and develop their material and human resources in order to achieve progress and advancement. At the top of these objectives is the development of educational process, which seeks to include many social, economic, cultural and environmental concepts, in addition to developing the skills acquired by the individual through education, so as to increase productivity through sustainable development.

The university education contributes to achieve the objectives of education. It is the first factor for sustainable social development in the preparation of qualified and trained human resources that directly affect continuous development. This makes universities able to cope with developments and changes in all fields. As societies are being changed and developed, the universities undertake to renew and develop new curricula and courses that accompany education, and make the sought change in educational learning process, so that the output of education and the requirements of the labor market will be harmonized (Bahi, 2011).

People began to live in groups; each group had goals to achieve, and a heritage to preserve it. Hence, it became important to provide environment suitable to cultures of these groups. Hence, the difference in educational process from one place to another has come, educational systems varied, that each of which has objectives and serving its political systems, which has been affected by colonial era that imposed the foreign culture. Education is the attainment of the thing to perfection, which is the adaptation to the natural and social surroundings' environment, and walk on the familiarity of values, customs and traditions of society, which are necessary for the community in order to preserve the cultural heritage and transfer it to the current and future generations. Education is flexible, inclusive, humanitarian and social process through which civilizations are developed by increased knowledge and science, in harmony with society and the nation (Ayasrah, 2012). 
The education derives its principles from the philosophy of the society in it, and this means that one aspect of the culture of society relates to the goals and aspirations from which the individual is directed to guide his activity. The education achieves a deeper and more comprehensive understanding of the idea of life. In order to preserve the philosophy of society, it is necessary to adopt a special education related to ideas, values and principles and beliefs the society believes in and applied, which is not absurd, but rather stems from the intellectual, social, and cultural system (Ammar, 2012).

The main goal of education is to prepare a generation that has lifelong learning skills and the ability to engage in dialogues on related issues, i.e., to prepare a culturally educated generation in all respects. Education must therefore be integrated internally and externally. The curriculum should be compatible and closely related to events. especially as education is the key to sustainable development, which aims at creating individuals who are capable of thinking about the future and shaping it accordingly, optimizing natural resources, communicating and communicating with others in a sustainable manner, sustainable development, and awareness of how to deal with contemporary challenges such as globalization, decision-making and industry (Walweal, 2011).

The role of educational tutorial to improve life and quality has become the responsibility of universities, and thus achieving sustainable development, and has become the integration of education with sustainable development goals sought by all educational institutions, including universities, and improve the performance of faculty members in all disciplines. The aim of which is to achieve a kind of sustainability institutional universities, and to what degree can these institutions achieve sustainable development of their communities.

Education is closely linked to economic and social issues. Sustainable development is carried out in three areas: economic growth, by providing the foundations of development, namely, money to solve problems and social development, by providing a secure and sustainable environment without diminishing the right of future generations. And giving attention to environment and preserve its natural resources, as based principles of education for sustainable development to involve the input of university education. These all aspects aimed at promoting thinking skills, and the use of viable educational methods working on positive change, and document the links between education and sustainable development to be integrated into the curriculum that making it important to integrate education with sustainable development in into learning process (Etoum, 2013).

As an inevitable result of rapid technological changes and the emergence of new concepts such as cultural, economic, and social globalization, the university has to face these changes to serve the educational learning process, increase knowledge production, focus on research that drives the development process and face the economic challenge of unemployed youth graduates to offer courses not meet the needs of labor market of trained manpower. This led to unemployment and delayed the wheel of development forward. Thereupon, its role is come to review programs to prevent the recurrence of saturated specializations on the one hand, and the education should go along with economic development plans, solve socio-economic problems and integrate scientific and research production in universities into sustainable development through the participation of officials, faculty members, and students in all sectors of the country to achieve this integration (Brake, 2014).

The universities are educational institutions the society depends on totally to disseminate its culture and realizes its aspirations, especially after its role has been transformed from just an institution that provides educational services to educational institutions that provide scientific development through sustainable education, in addition to the current acceleration of the world in all areas. Based on, the role of universities is brought out in benefiting from technology, developing of economy, and achieving sustainable development (Kurdi, 2016).

This requires university faculty members to have competencies that enable them to assist graduate students and researchers in reaching higher levels of academic excellence, developing their lives, refining their personalities, and encouraging them to engage in their communities by achieving integration between citizenship and education. As well as integration of knowledge with life and global issues, using teaching strategies focused on creativity, the involvement of students in the educational learning process, and encouraging them to research and survey, in all areas of education and sustainable development by creating programs and curricula keep pace with the present and fall under which topics of socio-economic environmental nature, related to society and its changes, and including concepts of responsibility for the current and subsequent generations. This is in addition to the inclusion of environment and development material as a resource to how dealing with, and provide an attractive campus environment embraces equipment necessary, to give students skills to enable them to engage in the labor market, and get ready to meet the needs of the community of sustainable development, Above this and that, faculty members must be correctly prepared to achieve sustainable development (Shann, 2017).

In view of the importance of universities in being a mirror of societies and leaders of development and progress, it can assist in preparing a generation capable of positive interaction with the issues of education and sustainable 
development. In light of the great role that universities must play in studying the situation of society and finding solutions to societal problems, the universities could not achieve the principles of sustainable development. Further, the university courses are lacking the integration of educational principles on sustainable development, and the university education programs are below the required level and not linked to sustainable development. For importance of the role played by university education in achieving sustainable development, the researchers are urged to develop a role for Jordanian universities to help them achieving their goals in this issue.

\subsection{Problem of Study}

The study is intending to adder the following questions:

What is the role of Jordanian universities in integrating the principles of education on sustainable development in the educational learning process according to faculty members' opinion?

\subsection{Target and Inquires of Study}

Study's goal is to probe the role of Jordanian universities in integrating the principles of sustainable development with the learning process through the following questions:

Question 1: What is the role assigned to Jordanian universities to achieve this goal?

Question 2: To what extent do statistical indications differ from the point of view of the study sample according to the type of faculty, academic rank and sex of the sample surveyed?

Question 3: What is the proposed educational role to integrate the principles of sustainable development education into the learning process from the point of view of academic staff at universities?

\subsection{Importance of the Study}

It is hoped that the following entities will benefit from the results of this study:

- Jordanian universities: in terms of offering courses that keep pace with the labor market, on the one hand, and developing the community and meeting the hopes and aspirations on the other hand.

- Researchers: by providing them with a theoretical framework on the role of Jordanian universities to integrate the principles of education on sustainable development in the educational learning process.

\subsection{Definition}

Educational role: "The tasks, duties, responsibilities and actions to be carried out. It said that your role is to do so and so; you have to perform this role" (Aldwairi, 2007).

Procedural: The tasks, actions, behaviors and practices of Jordanian universities in order to bring about the desired change in the development of educational learning process.

Jordanian universities: Educational institutions affiliated to the Jordanian Ministry of Higher Education and will apply its laws that to which the students can enroll after completing high school, for four or five years. It includes scientific and humanities colleges that is funded by the public funds.

Principles of Education: The concept of the principle "intellectual and ideological fundamentals the individual adheres mentally and emotionally that by which his behavior is reflected."

Education: is a mean of knowledge and evolution of concept by the development of societies. Education has become a way of preparing a person who is well suited to society and employs the sources of knowledge in problem solving. This is the gateway to a comprehensive development of all aspects of life. (Ibrahim, 2001)

Development: "Development and progress for the better, keeping abreast of rapid technological changes to include all aspects of life, and exploiting all material and human resources. These processes are based on coordinated, civil and governmental efforts" (Ibrahimi, 2015).

Sustainable development: "Moving from the current situation to a more advanced position to achieve goals aimed at raising the standard of living of the society in all aspects of urban, social and economic means by exploiting the material and human resources available, working on developing and increasing these resources, solving societal problems, And meet the needs of society in all environments "(Kubaisi, 2012).

Procedural: To develop and improve the needs of community by recognizing the importance of integrating education into sustainable development at the university level.

Teaching tutorial Process: The processes, practices and activities that occur within the classroom that aims to provide learners with theoretical and practical knowledge, or positive attitudes. It is a system consisting of inputs (learners) and operations (a coordination process of information, and outputs represented in educated graduates 
(Sahel, 2014).

\subsection{Limitation}

The study is limited in the following:

Human beings: college staff in Jordan official Universities.

Temporal: Academic year of 2017/2018

\subsection{Previous Related Research}

Some of the relevant studies are presented below for benefiting from their methodological procedures and theoretical literature they have included. They have been chronologically arranged from the oldest to latest:

A study by Roger and Christine (2010) entitled "Knowledge about Education for Sustainable Development", aimed to demonstrate the importance of education for sustainable development. The study sample consisted of teachers who obtained a graduate certificate from UK University. With a questionnaire as a method. It concluded that moral and political problems faced by teachers and there was an urgent need to remove tension between policies and school culture.

A study by (Escrigas, Polak and Jegede, 2011) entitled "Promotion of Sustainable Development by Higher Education of Institution in Sub-Saharan Africa sought to promote sustainable development in higher education institutions in South Africa. The study found that African universities face many challenges, such as low levels of sustainability in universities.

A study by (Offie, 2012), entitled "Education for Sustainable Development in Africa", aimed to demonstrate the importance of ESD education in Africa. School staff in Africa was the sample of study. The questionnaire was the study tool. ESD was not clear in Africa, but at present the pursuit of ESD has increased, yet this is still not clearly defined in educational practices.

A study by (Ahlam, Etoum, 2013) entitled "University education and its relation to achieving sustainable development in Jordanian society and proposals for development" aimed at revealing the role of university education and its relation to achieving sustainable development in Jordanian society. The study sample consisted of academic leaders in the universities of North Region. The study revealed that the role of university education and its relation to the achievement of sustainable development in Jordanian society were moderate, significance differences depending on the type of university, gender, academic position and experience were found.

A study by (Shatha, Brake, 2014) entitled "The Role of Vocational and Technical Education at Balqa' Applied University in Sustainable Development and Development Proposals", aimed to identify the role of vocational and technical education in Balqa' Applied University for sustainable development. Study concluded that the role of vocational and technical education in the Balqaa' Applied University in sustainable development was moderate. Significant differences Vis-à-vis the academic level variable for the students of the intermediate diploma. No significant differences for gender and members variable.

A study by (Mohammed, 2015) entitled "The Role of Universities in Achieving Sustainable Development in Sudan: A Case Study of Sudan University of Science and Technology" aimed at identifying sustainable development programs at Sudan University of Science and Technology. The study sample consisted of deans, heads of departments. The study concluded that the most important role of the University of Sudan in achieving sustainable development is the graduation of cadres in various specializations.

A work by (Nasir, 2015) entitled "The Role of Higher Education in Achieving Sustainable Development from the point view of Jerash University Students " aims to reveal the role of university education in achieving sustainable development according to students' opinion. The study sample consisted of Jerash University students. University level in achieving sustainable development was moderate, no differences attributed to sex and college variables.

A study by (Ekene \& Suleh, 2015) entitled, "Role of Institution of Higher Learning in Enhancing Sustainable development in Kenya", aimed at revealing the role of Marist College of Kenya in promoting sustainable development. The study sample consisted of college staff and graduates. The interview were a method. It concluded that the role of the college is clear in education of its students on development, and it is also faced with financial constraints and limited programs.

A study by (Bahi, 2015), entitled "What Role for Higher Education in Sustainable Development", aimed at demonstrating the ability of higher education to achieve sustainable development in Africa. The surveyed sample was all institutions of higher education in Africa. It concluded that all institutions should integrate development 
into teaching processes, and that education has a clear role in promoting sustainable development.

A study by (Al-Hoshani, 2016) entitled "A Proposal to Activate the Cultural Role of Female Teacher in Light of Directions of Education for Sustainable Development" aimed to identify reality of cultural role of the teacher in the light of the directions of education for sustainable development. The study sample consisted of the leaders of general education schools in Buraidah / Qassim region. The questionnaire was the mean of the study. It showed that the degree of practice of the teacher for the cultural role was moderate, as there were differences according to the variable stage of education for the primary stage, especially in favor of years of experience for the benefit of those having 5 years' experience and less, ,meninal change were attributed to specialization and qualification variable.

A study by (Shann, 2017) entitled "The Role of Pre-university Education Leaders in Southern Governorates of Palestine in Achieving the Requirements of Sustainable Development" aimed at identifying the efforts of pre-university education leaders in the southern provinces of Palestine in achieving the requirements of sustainable development. The sample of the study consisted of educational leaders in Gaza area. The study found that the utilization of educational leaders for technological innovations in achieving the dimensions of sustainable development in the southern governorates of Palestine was high, and there were no statistically significant differences due to gender, educational level, or length of time.

A study by (Shann, 2017) entitled, "The Degree of Relevance of the Performance of Educational leaders in pre-university educational institutions to the Requirements Sustainable Development in Palestine " aimed to determine the relevance performance degree of educational leaders in pre-university institutions to the requirements of sustainable development in Palestine. The study sample consisted of educational leaders in directorates of education. The study found that the relevance performance degree of educational leaders in pre-university education institutions to the requirements of sustainable development in Palestine was high, and the use of educational leaders for technological innovations in achieving sustainable development and its dimensions was also high.

\subsection{What Distigueshes this Study from Previuos Studies}

The previous studies clarified some related issues of the study, namely the study of (Tamara, Nasir 2015) and (Etoum , 2013), since the integration of the principles of education into the principles of sustainable development is important in various fields. Universities are the mirror of societies. Its goal is to prepare human cadres and graduate students who are able to meet the demands of the age, and link the educational system and university education with the needs of society. What makes this study different from above mentioned ones is its dealing with a new vital topic, which is a proposed role for Jordanian universities to integrate the principles of education into sustainable development in the educational learning process, which is not covered by any previous study as believed by researchers.

\section{Methodology}

The study depended on a descriptive approach as the best mean for such studies.

\subsection{Study Population}

Faculty staff in the Jordanian official universities like, Jodanian, Yarmouk and Mutah, present in the academic year of 2017/2018, totaled (10129). 


\subsection{The Study Sample}

A simple random sample was taken, consisting of (300) faculty members, as shown in the following table:

Table 1. Distribution of sample members by university, type of faculty, position and gender

\begin{tabular}{|c|c|c|c|c|c|c|c|c|c|c|}
\hline \multirow{2}{*}{$\begin{array}{l}\text { Type of } \\
\text { faculty }\end{array}$} & \multirow{2}{*}{ Position } & \multirow{2}{*}{$\begin{array}{l}\text { University } \\
\text { Gender }\end{array}$} & \multicolumn{2}{|c|}{$\begin{array}{c}\text { Jordan } \\
\text { University }\end{array}$} & \multicolumn{2}{|c|}{$\begin{array}{l}\text { Yarmouk } \\
\text { University }\end{array}$} & \multicolumn{2}{|c|}{$\begin{array}{c}\text { Muta } \\
\text { University }\end{array}$} & \multicolumn{2}{|c|}{ Total } \\
\hline & & & No. & $\%$ & No. & $\%$ & No. & $\%$ & No. & $\%$ \\
\hline \multirow{6}{*}{ Scientific } & \multirow{2}{*}{ professor } & Male & 14 & 4.7 & 12 & 4.0 & 4 & 1.3 & 30 & 10.0 \\
\hline & & female & 7 & 2.3 & 5 & 1.7 & 7 & 2.3 & 19 & 6.3 \\
\hline & \multirow{2}{*}{ Co-professor } & Male & 15 & 5.0 & 13 & 4.3 & 8 & 2.7 & 36 & 12.0 \\
\hline & & female & 10 & 3.3 & 8 & 2.7 & 6 & 2.0 & 24 & 8.0 \\
\hline & \multirow{2}{*}{$\begin{array}{l}\text { Assistant } \\
\text { Professor }\end{array}$} & Male & 13 & 4.3 & 7 & 2.3 & 11 & 3.7 & 31 & 10.3 \\
\hline & & female & 7 & 2.3 & 12 & 4.0 & 6 & 2.0 & 25 & 8.3 \\
\hline \multirow{7}{*}{ Humanitarian } & \multirow{2}{*}{ professor } & Male & 14 & 4.7 & 8 & 2.7 & 6 & 2.0 & 28 & 9.3 \\
\hline & & female & 5 & 1.7 & 10 & 3.3 & 8 & 2.7 & 23 & 7.7 \\
\hline & \multirow{2}{*}{ Co-professor } & Male & 10 & 3.3 & 13 & 4.3 & 8 & 2.7 & 31 & 10.3 \\
\hline & & female & 5 & 1.7 & 6 & 2.0 & 8 & 2.7 & 19 & 6.3 \\
\hline & \multirow{2}{*}{$\begin{array}{l}\text { Assistant } \\
\text { Professor }\end{array}$} & Male & 4 & 1.3 & 6 & 2.0 & 7 & 2.3 & 17 & 5.7 \\
\hline & & female & 6 & 2.0 & 5 & 1.7 & 6 & 2.0 & 17 & 5.7 \\
\hline & Total & & 110 & 36.7 & 105 & 35.0 & 85 & 28.3 & 300 & 100.0 \\
\hline
\end{tabular}

\subsection{Study Instrument}

The study aimed to identify a role proposal for Jordanian universities to integrate the principles of education on sustainable development in the educational learning process. To achieve the goal of study and answer its questions, the theoretical literature on the subject of previous study and related issues has been reviewed, such as the study of (Muhammad, 2015) and (Shatha Break, 2014); a questionnaire consisting of (25) items was developed, and triple Likert scale was used (high, medium, and law degrees).

\subsection{Questionnaire Authority}

The questionnaire was presented to ten arbitrators in educational administration to ensure the tool in terms of construction and language integrity and clarity, and the observations of all arbitrators were taken.

\subsection{Questionnaire Reliabilty}

To verify the stability of the questionnaire, the coefficients of Kronbach's $\alpha$ stability were found for the resolution paragraphs (0.8859)

\subsection{Study Variables}

The study included the following variables:

Independent: Integrating governance principles into sustainable development in the educational process.

Dependent: The response degree of faculty members in the Jordanian public universities, namely, the University of Jordan, Yarmouk University, and Mu'tah University.

Medium: Gender: male, female.Type of College: scientific and humanitarian colleges.

\subsection{Statistical Processing Methods}

To achieve the objectives of the study, the Statistical Package for Social Sciences (SPSS) was used to analyze the data and obtain the results as follows:

- Frequencies and percentages to describe the characteristics of the study sample. 
- Mean averages and standard deviations to identify the responses of the sample members on each item of questionnaire.

- Cronbach's Alpha to verify the reliability of questionnaire.

- T-test for independent samples to find out significant differences between two independent groups.

- One-way ANOVA analysis to define the significant differences between more than two independent groups.

- LSD test to compare between categories of a variable

\section{Study Result}

The results of the study are shown below.

\subsection{Results Related to the Question 1}

What is the role of Jordanian universities to integrate the principles of education on sustainable development in the educational learning process from the point of view of faculty members?

To answer this question, the arithmetical averages, the standard deviations and the order of the scores of sample's respondents were calculated on the question paragraphs. The results were as follows:

Table 2. Arithmetical averages, standard deviations, and order of the approval ratings of sample members on the questionnaires

\begin{tabular}{|c|c|c|c|c|c|}
\hline No. & Paragraph & $\begin{array}{l}\text { Arithmetical } \\
\text { Average }\end{array}$ & $\begin{array}{l}\text { Deviation } \\
\text { Standard }\end{array}$ & $\begin{array}{l}\text { Approval } \\
\text { Degree }\end{array}$ & Order \\
\hline 16 & $\begin{array}{l}\text { The University is interested in the development of different } \\
\text { disciplines within different faculties }\end{array}$ & 2.40 & 0.689 & High & 1 \\
\hline 1 & $\begin{array}{l}\text { The University provides sustainable education to all } \\
\text { segments of society }\end{array}$ & 2.38 & 0.706 & High & 2 \\
\hline 20 & $\begin{array}{l}\text { The University develops environmental responsibility } \\
\text { within its courses }\end{array}$ & 2.33 & 0.691 & Medium & 3 \\
\hline 14 & $\begin{array}{c}\text { University balances between education requirements and } \\
\text { productivity }\end{array}$ & 2.29 & 0.762 & Medium & 4 \\
\hline 26 & $\begin{array}{c}\text { University courses combine knowledge with community } \\
\text { and global issues }\end{array}$ & 2.29 & 0.759 & Medium & 5 \\
\hline 25 & $\begin{array}{c}\text { University education focuses on integrating the principles of } \\
\text { development into education in the educational learning } \\
\text { process }\end{array}$ & 2.27 & 0.726 & Medium & 6 \\
\hline 23 & $\begin{array}{l}\text { The university focuses on education from the idea that it is } \\
\text { the key to sustainable development }\end{array}$ & 2.26 & 0.762 & Medium & 7 \\
\hline 2 & $\begin{array}{l}\text { University education is harmonized between the three } \\
\text { university functions }\end{array}$ & 2.21 & 0.734 & Medium & 8 \\
\hline 9 & $\begin{array}{c}\text { The university links its outputs to the requirements of the } \\
\text { labor market }\end{array}$ & 2.21 & 0.704 & Medium & 9 \\
\hline 10 & University research focuses on community service & 2.21 & 0.692 & Medium & 10 \\
\hline 24 & University education addresses contemporary challenges & 2.21 & 0.781 & Medium & 11 \\
\hline 11 & $\begin{array}{l}\text { The university gives priority to the knowledge economy to } \\
\text { be focused on }\end{array}$ & 2.20 & 0.661 & Medium & 12 \\
\hline 22 & $\begin{array}{c}\text { The university considers the process of education as a } \\
\text { productive investment }\end{array}$ & 2.20 & 0.707 & Medium & 13 \\
\hline 27 & The University promotes multiple thinking skills & 2.20 & 0.772 & Medium & 14 \\
\hline 7 & $\begin{array}{c}\text { The University develops its courses based on sustainable } \\
\text { development plans }\end{array}$ & 2.19 & 0.681 & Medium & 15 \\
\hline
\end{tabular}




\begin{tabular}{|c|c|c|c|c|c|}
\hline 3 & $\begin{array}{l}\text { University education focuses on education for sustainable } \\
\text { development }\end{array}$ & 2.17 & 0.657 & Medium & 16 \\
\hline 6 & $\begin{array}{l}\text { University education is eager to find solutions to problems } \\
\text { faced by society }\end{array}$ & 2.17 & 0.731 & Medium & 17 \\
\hline 13 & $\begin{array}{l}\text { University courses demonstrate the importance of } \\
\text { sustainable development }\end{array}$ & 2.17 & 0.700 & Medium & 18 \\
\hline 8 & $\begin{array}{l}\text { The University is interested in the theoretical and applied } \\
\text { aspects of education as well }\end{array}$ & 2.16 & 0.726 & Medium & 19 \\
\hline 18 & $\begin{array}{l}\text { The university contributes to solving the problem of } \\
\text { unemployment through its specializations that suit the labor } \\
\text { market }\end{array}$ & 2.16 & 0.717 & Medium & 20 \\
\hline 17 & The University develops self-responsibility with its inputs & 2.15 & 0.711 & Medium & 21 \\
\hline 19 & $\begin{array}{c}\text { The university links interdisciplinary and labor market } \\
\text { requirements }\end{array}$ & 2.12 & 0.717 & Medium & 22 \\
\hline 12 & $\begin{array}{c}\text { University education is accompanied by technological } \\
\text { development }\end{array}$ & 2.09 & 0.692 & Medium & 23 \\
\hline 28 & $\begin{array}{l}\text { The University balances its role in achieving scientific } \\
\text { development and sustainable development }\end{array}$ & 2.09 & 0.771 & Medium & 24 \\
\hline 30 & $\begin{array}{c}\text { The University is keen on internal and external educational } \\
\text { integration }\end{array}$ & 2.09 & 0.800 & Medium & 25 \\
\hline 21 & $\begin{array}{l}\text { The university coordinates with different sectors of the state } \\
\text { and its requirements }\end{array}$ & 2.08 & 0.716 & Medium & 26 \\
\hline 5 & $\begin{array}{l}\text { University education links sustainable development to } \\
\text { development plans }\end{array}$ & 2.09 & 0.645 & Medium & 27 \\
\hline 29 & $\begin{array}{l}\text { The university prepares its graduates from the demand for } \\
\text { integration into the labor market }\end{array}$ & 2.07 & 0.733 & Medium & 28 \\
\hline 15 & $\begin{array}{l}\text { University courses focus on demonstrating the creativity of } \\
\text { their application }\end{array}$ & 2.06 & 0.782 & Medium & 29 \\
\hline \multirow[t]{2}{*}{4} & $\begin{array}{l}\text { University education contributes to raising the standard of } \\
\text { living }\end{array}$ & 2.04 & 0.693 & Medium & 30 \\
\hline & General average & 2.19 & 0.347 & Medium & \\
\hline
\end{tabular}

The table 2 shows that the arithmetic averages of the approval degrees of sample's respondents ranged from 2.04 to 2.40 , where paragraphs $(16,1)$ obtained large approval scores that paragraph $(16)$ was the highest " The University is interested in the development of different disciplines within different faculties", which obtained the highest average score by (2.40), while the rest of the paragraphs obtained the middle degrees of approval which paragraph (4) was the lowest, "university education contributes to raising the standard of living".

The table also shows that the total number of paragraphs has a mean average of 2.19 and a medium degree of approval. This indicates that the role of Jordanian universities to integrate the principles of education on sustainable development in the educational learning process from the point of view of faculty members was medium.

\subsection{Results of Question 2}

Are there statistically significant differences in the estimates of the sample members of the study to integrate the principles of education on sustainable development in the educational learning process from the point of view of the faculty members due to type variable of college, academic position and gender?

\subsubsection{By type of College}

To answer this question, the arithmetical averages and standard deviations of estimates the sample of the study were calculated to integrate the principles of education on sustainable development in the educational learning process according to the type of college variable and using $T$ test to determine the significance of the differences between these averages. 
Table 3. Results of $\mathrm{T}$ test for independent samples to set the significance of differences in arithmetic averages of estimates of the study sample to integrate the principles of education for sustainable development in the educational process of learning depending on the variable type of college

\begin{tabular}{ccccccc}
\hline $\begin{array}{c}\text { Type of } \\
\text { faculty }\end{array}$ & No. & $\begin{array}{c}\text { Arithmetical } \\
\text { Average }\end{array}$ & $\begin{array}{c}\text { Standard } \\
\text { deviation }\end{array}$ & Value of "T" & $\begin{array}{c}\text { Degrees of } \\
\text { freedom }\end{array}$ & $\begin{array}{c}\text { significance } \\
\text { Level }\end{array}$ \\
\hline Scientific & 165 & 2.26 & 0.333 & 4.357 & 298 & 0.000 \\
Humanitarian & 135 & 2.09 & 0.342 & & & \\
\hline
\end{tabular}

The table 3 shows that the value of the level of significance is $(0.000)$ which is less than $(0.05)$. This indicates that there are statistically significant differences in the estimates of the study sample to integrate the principles of education on sustainable development in the educational learning process according to the type of college variable. These differences were found to be in favor of scientific colleges. This indicates that the estimates of faculty members in scientific colleges to integrate the principles of education on sustainable development into the educational learning process were higher than those of faculty members in humanitarian faculties.

\subsubsection{By Academic Position}

In order to answer this question, the arithmetical averages and standard deviations were calculated for the estimates of the study sample. The study sample was used to integrate the principles of education on sustainable development into the educational process according to the academic level variable. The results were as follow:

Table 4. Statistical averages and standard deviations of estimates of study sample to integrate the principles of education into sustainable development in the educational process of learning depending on the variable of academic position

\begin{tabular}{cccc}
\hline Academic level & Number & $\begin{array}{c}\text { Arithmetical } \\
\text { average }\end{array}$ & Standard deviation \\
\hline Professor & 100 & 2.26 & 0.385 \\
Co-professor & 110 & 2.14 & 0.281 \\
Assistant Professor & 90 & 2.16 & 0.366
\end{tabular}

The table 4 shows that there are apparent differences in the estimates of the study sample to integrate the principles of education on sustainable development in the educational process according to academic level variable. To find out the significance of these differences, the one-way ANOVA test was made and the results were as follows:

Table 5. One-way ANOVA test to find out the significance of differences in the estimates integrate the principles of education into sustainable development in the educational process of learning depending on the variable of academic position

\begin{tabular}{cccccc}
\hline Source of Variance & Total squares & $\begin{array}{c}\text { Degrees of } \\
\text { freedom }\end{array}$ & $\begin{array}{c}\text { Average } \\
\text { squares }\end{array}$ & (P) Value & $\begin{array}{c}\text { Level of } \\
\text { significance }\end{array}$ \\
\hline Between groups & 0.887 & 2 & 0.443 & & \\
Within groups & 35.140 & 297 & 0.118 & 3.747 & 0.025 \\
Total & 36.027 & 299 & & &
\end{tabular}

The table shows statistically significant differences at level of less than (0.05) in the estimates of the study sample to integrate the principles of education on sustainable development in the educational process according to academic level variable and to know between which academic grades the differences is existed. The results were as follows. 
Table 6. LSD Test to compare academic grade categories in the estimates of study sample To integrate the principles of education on sustainable development into the educational learning process

\begin{tabular}{cccc}
\hline Position & $\begin{array}{c}\text { Arithmetical } \\
\text { average }\end{array}$ & Co-professor & Assistant Professor \\
\hline Professor & 2.26 & $*$ & $*$ \\
Co-professor & 2.14 & & \\
Assistant Professor & 2.16 & & \\
\hline
\end{tabular}

\section{* Statistically difference}

The table 6 shows statistically significant differences at the level of $(0.05)$ in the estimates of the study sample to integrate the principles of education on sustainable development in the educational process between the position of professor and assistant professor for the benefit of professor. However, the views of faculty members with the position of professor were the highest estimates in recognition of the integration of the principles of education on sustainable development in the educational process of the faculty members with the associate professor or assistant professor positions.

\subsubsection{By Gender}

To answer this question, the arithmetical averages and standard deviations were calculated to estimate the sample of the study to integrate the principles of education on sustainable development into the learning process according to gender variable and $\mathrm{T}$ test was used to find out the significance of the differences between these averages.

Table 7. $\mathrm{T}$ test results for independent samples to find out the significance of differences in the arithmetic averages of estimates of study sample to integrate the principles of education for sustainable development in the educational process of learning depending on gender variable

\begin{tabular}{ccccccc}
\hline Gender & Number & $\begin{array}{c}\text { Arithmetical } \\
\text { average }\end{array}$ & $\begin{array}{c}\text { Standard } \\
\text { deviation }\end{array}$ & "T" Value & $\begin{array}{c}\text { Freedom } \\
\text { degrees }\end{array}$ & $\begin{array}{c}\text { Level of } \\
\text { significance }\end{array}$ \\
\hline Males & 173 & 2.08 & 0.354 & -6.702 & 298 & 0.000 \\
Female & 127 & 2.33 & 0.278 & & &
\end{tabular}

The table 7 shows that the value of the significance level is $(0.000)$ which is less than (0.05). This indicates that there are statistically significant differences in the estimates of the study sample to integrate the principles of education on sustainable development in the educational learning process according to gender variable. The arithmetical averages indicate that that these differences were in favor of females. This indicates that the estimates of female faculty members to integrate the principles of education on sustainable development into the educational learning process were higher than those of male faculty members.

\subsection{Question 3}

What is the proposed educational role of Jordanian universities to integrate the principles of education on sustainable development into the educational learning process?

Title of role: The role of the proposed educational role of Jordanian universities to integrate the principles of education on sustainable development in the educational learning process.

Objectives of the proposed educational role:

General Objectives: The proposed educational role aims to integrate the principles of education on sustainable development into the educational learning process.

Special objectives: To integrate the principles of education on sustainable development in the educational process of learning in Jordanian universities, namely, the University of Jordan, Yarmouk University and Mu'tah University. All educational institutions can benefit from the vision for achieving integration and interaction between the educational process and sustainable development. As well as to keep abreast of sustainable development, and direct university scientific research to achieve sustainable development, and keep up with the universities between their outputs and the demands of the labor market.

Importance of the educational role: Universities have become the leaders of change and development in the 
societies because of their leading role in sustainable development and their expected role in achieving sustainable development education, building human beings in all aspects, creating opportunities for creativity and renewal, and reconnect the relationship between higher education, environment and society, and the interest of universities to achieve sustainable development in the educational process of learning.

\section{Result Discussion}

\subsection{Discussion of the Result Related to Question (1)}

What is the role of Jordanian universities to integrate the principles of education on sustainable development in the educational learning process from the point of view of faculty members?

When the result indicates that the role of Jordanian universities to integrate the principles of education on sustainable development in the educational learning process from the point of view of faculty members was medium.

The study attributed this result to the fact that Jordanian universities are very keen to promote the educational process at the university. It is keen to develop the competencies of faculty members in the university and take into account technological developments.

The paragraph that received the lowest average math is attributed to the fact that faculty members believe that university education does not contribute to raising the standard of living due to the lack of links between university education and sustainable development, the lack of investment in education. The observer of the economic role of universities in the development of societies sees gloom of this role. The result was similar with the Etoum's study (2013), Brake study (2014), Nasir (2015), Al-Hoshani (2016), and differed with Shann (2017).

\subsection{Results Related to Question (2)}

Are there statistically significant differences in the estimates of the sample members of the study to integrate the principles of education on sustainable development in the educational learning process from the point of view of the faculty members due to type variable of college, academic position and gender?

\subsubsection{Type of college}

The differences were found to be in favor of scientific colleges. The result is due to the fact that the scientific faculties are closely related to society and reality and keep abreast of the scientific developments and the society's attitudes towards sustainable development, as well as their distance from stereotyping in teaching by focusing on discussion and dialogue and developing the students' personality in dealing with societal issues in a scientific way. It aims to focus on creativity and innovation. This result was similar to the study of Al-Hoshani (2016), and differed with the study of Break (2014) and Nasir (2015).

\subsubsection{Academic Position}

A significant differences at the level of (0.05) in the estimates of the study sample to integrate the principles of education on sustainable development in the educational process between the position of professor and assistant professor for the benefit of professor. This result is attributed to the fact that faculty members with professor position have a long experience in university teaching, writing research, providing services to the community, as well as possessing scientific and cognitive characteristics. The faculty members are professors who represent living models of community service and developing sustainable support. This result was similar to that of Etoum (2013).

\subsubsection{Gender}

The arithmetical averages indicate that that these differences were in favor of females. This indicates that the estimates of female faculty members to integrate the principles of education on sustainable development into the educational learning process were higher than those of male faculty members.

This result may be attributed to the fact that it is the responsibility of females to prepare the generation of the future, the conscious, the educated, and the most capable of raising young children right and wrong. The education that followed females and the education of females is a process of human development. The result is similar with the study of Etoum (2013), and differed with the study of Break (2014), Nasir (2015), and Shann (2017).

\subsubsection{Question 3}

What is the proposed educational role of Jordanian universities to integrate the principles of education on sustainable development into the educational learning process? 
Based on the study results, the study suggests the following educational role:

- Develop curricula incorporating the principles of education on sustainable development.

- Using teaching methods by faculty members that are directly proportional to the principles of education and sustainable development, and re-forming university goals to serve the partnership with the community, while encouraging meaningful dialogue and discussions on the problems faced by communities and universities, and providing opportunities for all students to share views, decision making, and integration between educational institutions and community institutions.

4.2.5 Recommenadtion

Based on the findings of the study, the study recommends the following:

- The degree of statistical averages and standard deviations of the role of Jordanian universities to integrate the principles of education on sustainable development in the educational learning process from the point of view of faculty members was medium. Therefore, the study recommends that the Ministry of Higher Education should review its plans and curricula and improve them so that the principles of education on sustainable development and enhance the cooperation between educational institutions and social and economic institutions of community to formulate plans and develop new disciplines that keep pace on integrating the education principles on sustainable development.

- Adopting the proposed educational role to bring about the desired change in the educational process.

\section{References}

Aldwairi, Fayez (2007). Role of public universities in promoting the concept of national security. Unpublished $\mathrm{PhD}$ thesis, University of Jordan, Amman, Jordan.

Al-Hoshani, Mona (2016). A Suggested Proposal for Enabling the Cultural Role of the Female Teacher in Light of Trends in Education for Sustainable Development. Unpublished Master thesis, Qassim University, Saudi Arabia.

Ammar, Eman (2015). Education and Human Rights. Future Journal of Arab Education Egypt, 22(95), 371-380.

Ayasrah, Wafaa (2012). Philosophical Educational Degree of Reflection (Idealism, Realism, and Pragmatism) on the Educational Process in Jordan. Unpublished $\mathrm{PhD}$ thesis, Yarmouk University, Irbid, Jordan.

Bahi, Ghulam (2011). Higher education is a social responsibility. International Conference on Higher Education, Riyadh, Saudi Arabia.

Brake, Shatha (2014). Role of Vocational and Technical Education at Balqa' Applied University in Sustainable Development and Development Proposals. Unpublished PhD Thesis, Yarmouk University, Irbid, Jordan.

Ekene \& Suleh, E. (2015). Role of Institution of Higher Learning in Enhancing Sustainable development in Kenya. Journal of Education and Practice, 6(16), 2222-1735.

Escrigas, C., Polak, E. \& Jegede, O. (2015). Promotion of Sustainable Development by Higher Education of Institution in Sub-Saharan Africa. AJSD, 4(3), 17-38.

Etoum, Ahlam (2013). University education and its relation to the achievement of sustainable development in the Jordanian society and proposals for development. Unpublished PhD thesis, Yarmouk University, Irbid, Jordan.

Ibrahimi, Nadia (2015). Role of the university in achieving sustainable development: a study of reality of Algerian universities. Al-Hikma Journal of Economic Studies - Al-Hikma Foundation - Algeria, 24(1), 260-282.

Kubaisi, Ahmed (2012). Sustainable Development in Arab World. Doha Magazine, 55(1), Doha, Qatar, 320-340.

Kurdi, Zuhair (2016). Proposed strategy for developing the changing leadership in institutions of higher education in Gaza governorates in light of sustainable development principles: Islamic University - case study. Unpublished Master Thesis, Islamic University, Gaza, Palestine.

Mohamed Bahi, G. (2015). What Role for Higher Education in Sustainable Development. University World News, Sustainable Development. Retrieved: March 5, 2016, from: http: // www. University World News.Com-Article.

Mohammed, Ahmed (2015). The Role of Universities in Achieving Sustainable Development in Sudan: A Case Study of Sudan University of Science and Technology. Jerash Journal for Research and Studies - Jordan, 1(16), 315-340. 
Nasir Tamara (2015). The Role of Higher Education in Achieving Sustainable Development from the point view of Jerash University Students. Jerash Journal for Research and Studies, Jordan, 1(16), 393-412.

Nasser, Ibrahim (2001). Philosophies of Education. Amman: Wael Publisher.

Offie, O. (2012). Education for Sustainable Development in Africa. International of Educational Development, 32(3), 367-383. https://doi.org/10.1016/j.ijedudev.2011.08.005

Roger, W. \& Christine, R. (2010). Knowledge about Education for Sustainable Development for Case Studies of Student Teachers in English Secondary Schools. Journal of Education Teaching, 33(3), 341-359. https://doi.org/10.1080/02607470701450528

Sahel, Layla (2014). Reality of educational process between Old and Contemporary Eras. Makhbar Journal, University of Biskra, Algeria, 10(1), 66-86.

Shann, Ali (2017). Role of pre-university education leaders in the southern governorates of Palestine in achieving the requirements of sustainable development. Journal of Palestine University for Research and Studies - Deanship of Graduate Studies and Scientific Research - Gaza - Palestine, 2(7), 61-90.

Shann, Ali (2017). The Degree of Relevance of the Performance of Educational leaders in pre-university educational institutions to the Requirements Sustainable Development in Palestine. International Specialized Educational Journal - Jordan Society for Psychology - Jordan, 6(7), 137-150.

Walweal, Wassef (2011). Proposed Principle of Educational Dealing with the Initial Aspects of the Jordanian Educational Crisis in the Twenty First Century. Unpublished PhD thesis, University of Jordan, Amman, Jordan.

\section{Copyrights}

Copyright for this article is retained by the author(s), with first publication rights granted to the journal.

This is an open-access article distributed under the terms and conditions of the Creative Commons Attribution license (http://creativecommons.org/licenses/by/4.0/). 